\title{
СТАНКОИНСТРУМЕНТАЛЬНАЯ ОТРАСЛЬ РОССИИ В 2019 ГОДУ: ЦИФРЫ И ФАКТЫ
}

\section{ГеоргИй САМОДУРОВ, ДмитрИЙ ЛАХТЮХОВ}

В современных экономических условиях проблема трансформации станкоинструментальной отрасли в направлении наращивания технологического потенциала, повышения конкурентоспособности и внедрения концепции «Индустрии 4.0» становится все более актуальной. Решению этих проблем в значительной степени посвящена деятельность Российской Ассоциации производителей станкоинструментальной продукции «Станкоинструмент» (далее - Ассоциация). В рамках этой работы, в отчетном докладе Ассоциации был дан анализ состояния отрасли, перспектив ее развития и путей решения ключевых проблем.

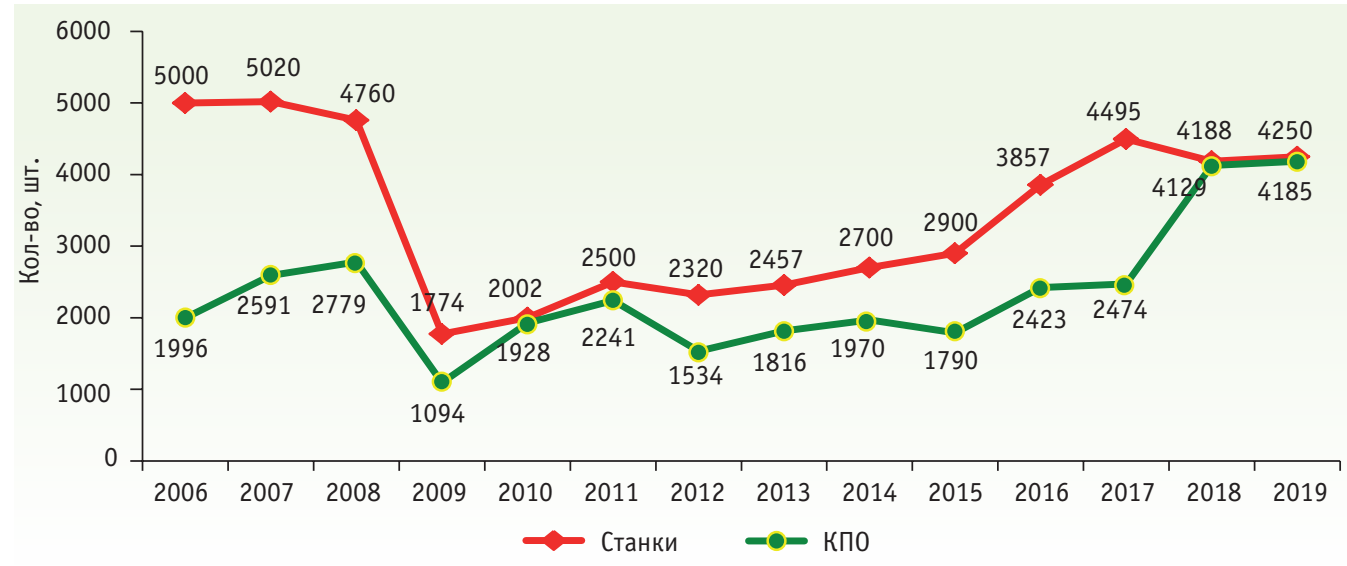

Puc. 1. Производство металлообрабатывающего оборудования (М00) в Российской Федерации в 2019 году по данным Росстата, 2019 год - прогноз

Представленные на рис. 1 данные показывают, что в последние годы наблюдается рост производства МОО.

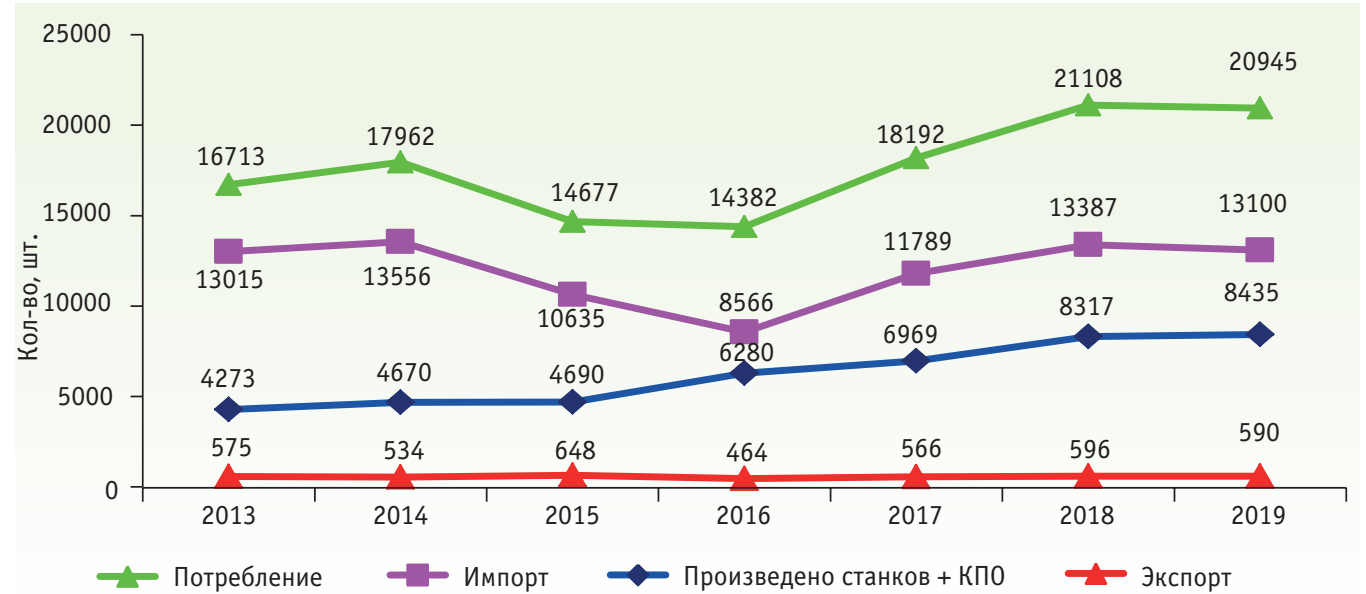

Puc. 2. Потребление М00 в 2013-2019 годах, 2019 год - прогноз 
В сравнении с 2018 годом произошел рост производства оборудования, составивший в 2019 году всего лишь 1,4\% при отсутствии роста объема внутреннего рынка его потребления (рис. 2). Экспорт оборудования снизился на 1,0\% при уменьшении импорта на 2,0\%.

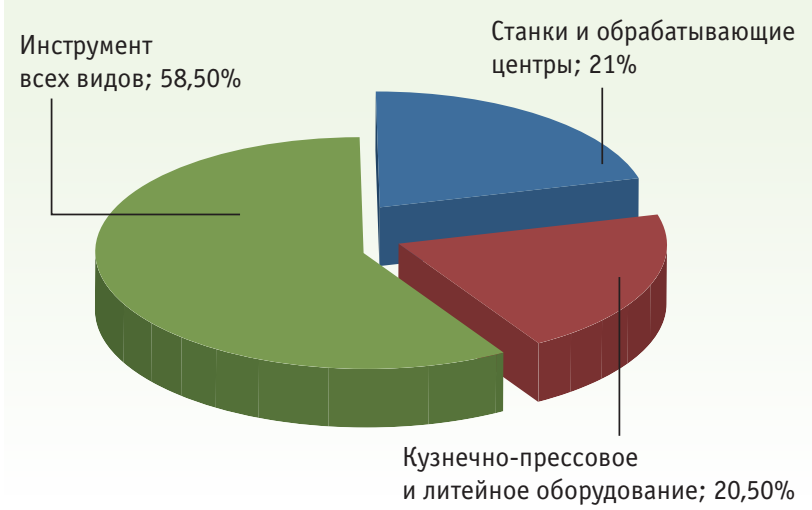

Puc. 3. Производство станков, кузнечно-прессового и литейного оборудования, измерительных машин и инструмента предприятиями Ассоциации в 2019 году (в стоимостном выражении)

Производство по видам технологического оборудования, контрольно-измерительных приборов и инструмента в стоимостном выражении составило: металлорежущих станков - 8021,7 млн руб., станков с ЧПУ - 6766,8 млн руб., кузнечно-прессового и литейного оборудования - 4 193,6 млн руб., контрольно-измерительных машин и инструмента - 86,6 млн руб. (рис. 3).
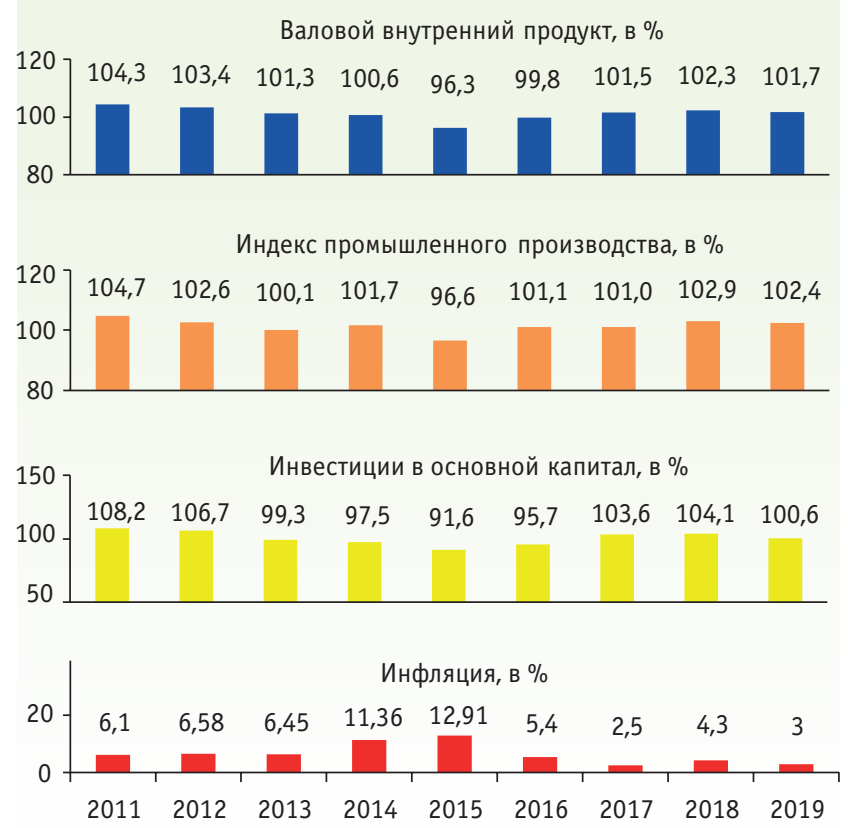

Puc. 4. Важнейшие экономические показатели РФ в 2011-2019 годах
Из представленной диаграммы (рис. 4) видно, что все показатели в сравнении с 2018 годом ухудшились, хотя инфляция снизилась с 4,3 до $3 \%$.

Вместе с тем за последние три года собираемость налогов (НДС, на прибыль, имущество, землю и др.) увеличилась в среднем от 11 до 20\%. В то же время просроченная задолженность предприятий в 2018 году увеличилась на $18 \%$, а в 2019 году - на $12 \%$. В 2018 году количество предприятий сократилось на 9\% (с 319 тыс. до 290 тыс.), а в 2019 году - на 7\%, согласно статистике.

В сфере обрабатывающей промышленности за 2018 год произошла ликвидация 41 тыс. предприятий.

В такой неоднозначной ситуации настораживает то обстоятельство, что Центральный банк РФ единственный банк в мире, который призван обеспечивать любой ценой инфляцию на уровне $4 \%$, но при этом не несет никакой ответственности в стране за экономический рост, развитие промышленности, рабочие места и другие социально важные проблемы. Такие задачи прописаны Банку России на 2019-2021 годы.

Ассоциация «Станкоинструмент» готова подготовить соответствующее обращение в адрес президента и премьер-министра.

\section{Таблица 1. Ключевые показатели финансового состояния отрасли}

\begin{tabular}{|c|c|c|c|c|}
\hline \multirow{2}{*}{$\begin{array}{l}\text { Объемы } \\
\text { производства, } \\
\text { рынка экспорта }\end{array}$} & \multicolumn{4}{|c|}{ Годы } \\
\hline & 2016 & 2017 & 2018 & 2019 \\
\hline $\begin{array}{l}\text { Объемы внутреннего } \\
\text { рынка (станкоинстру- } \\
\text { ментальная отрасль), } \\
\text { млрд руб. }\end{array}$ & 83,8 & 91,4 & 93,5 & 94,2 \\
\hline $\begin{array}{l}\text { Объемы производства } \\
\text { продукции (станкоин- } \\
\text { струментальная } \\
\text { отрасль), млрд руб. }\end{array}$ & 23,8 & 29,0 & 31,8 & 37,4 \\
\hline $\begin{array}{l}\text { Объемы производства } \\
\text { продукции станкострое- } \\
\text { ния, млрд руб. }\end{array}$ & 11,8 & 14,1 & 14,7 & 16,9 \\
\hline $\begin{array}{l}\text { Объемы производства } \\
\text { инструментальной } \\
\text { продукции, } \\
\text { млрд руб. }\end{array}$ & 12,0 & 14,9 & 17,1 & $\begin{array}{l}20,5 \\
\text { (про- } \\
\text { гно3) }\end{array}$ \\
\hline $\begin{array}{l}\text { Объемы экспорта } \\
\text { станкоинструментальной } \\
\text { продукции, } \\
\text { млрд руб. } \\
\text { (млн долл.) }\end{array}$ & $\begin{array}{c}1,3 \\
(18,7)\end{array}$ & $\begin{array}{c}1,4 \\
(24,7)\end{array}$ & $\begin{array}{c}1,55 \\
(26,9)\end{array}$ & $\begin{array}{c}1,85 \\
(28,8)\end{array}$ \\
\hline
\end{tabular}


Из приведенной табл. 1 видно, что внутренний рынок есть и для его роста имеются резервы наших возможностей, несмотря на экспансию на $70-80 \%$ иностранными поставщиками.

1. По данным Росстата, объем внутреннего рынка потребления в станкоинструментальной отрасли, включая аддитивные технологии, остался, практически, на уровне 2018 года и составил $0,7 \%$.

2. Рост объемов производства продукции станкостроения, включая КПО, составил $15,0 \%$ к уровню 2018 года.

3. Рост объемов производства инструментальной продукции составил 19,8\% к уровню 2018 года.

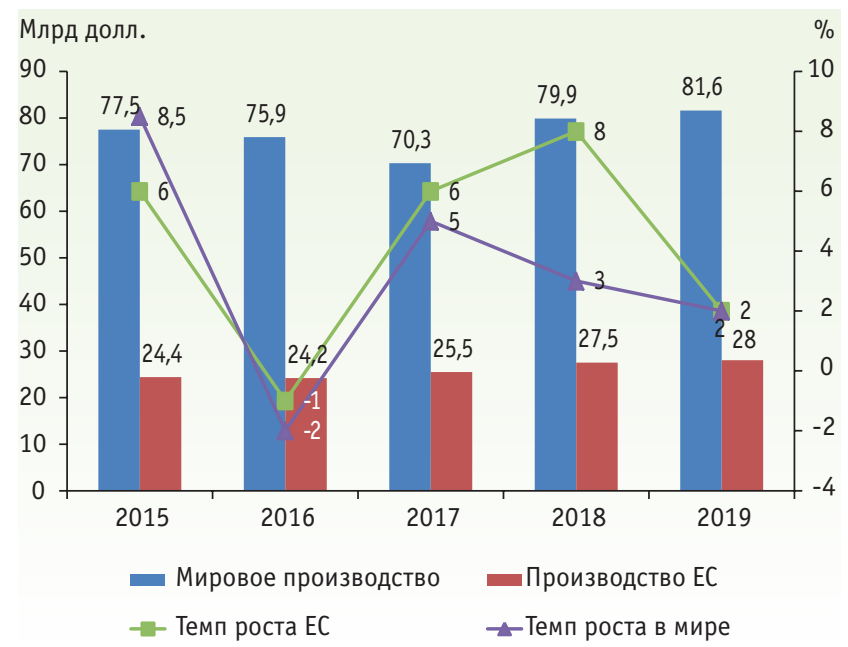

PUC. 5. Производство и темпы роста станкостроительной продукции в мире и в странах ЕС

Производители металлообрабатывающего оборудования в странах ЕС все больше уступают свои позиции (рис. 5). Центр производства оборудования пере- мещается в страны Юго-Восточной Азии. В 2019 году США несколько снизили темпы роста производства оборудования.

В 90-х и начале 2000-х годов все производство металлообрабатывающего оборудования было перебазировано в страны Юго-Восточной Азии, а позже оно вернулось и сегодня находится в прежнем состоянии.

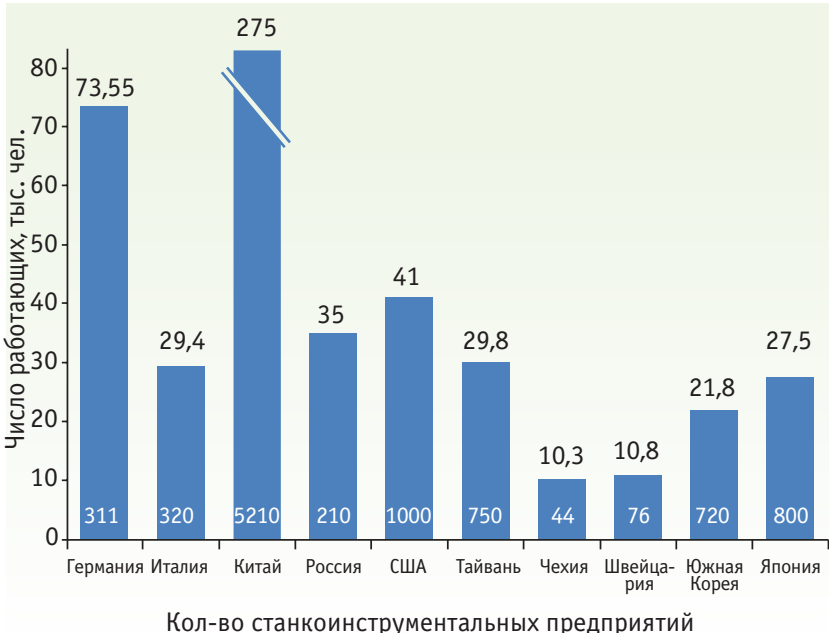

Puc. 6. Численность работающих и количество предприятий отрасли в странах-лидерах производства МО0 в 2019 году

Диаграмма (рис. 6) подтверждает тезис о том, что, при выборе типа предприятия, сегодня предпочтительным является сборочное производство, когда на этой площадке разрабатываются конструкции и ключевые узлы с набором компетенций, определяющие качество готового изделия, а все остальное работает в рамках кооперации.

\section{РЕШЕНИЯ, ДЕЙСТВУЮЩИЕ В 2019 ГОДУ В СТАНКОИНСТРУМЕНТАЛЬНОЙ ОТРАСЛИ}

$\rightarrow$ Постановление Правительства Российской Федерации от 23 февраля 2019 года № 191 «0 государственной поддержке организаций, реализующих корпоративные программы повышения конкурентоспособности, и внесении изменения в Правила предоставления из федерального бюджета субсидии в виде имущественного взноса Российской Федерации в государственную корпорацию «Банк развития и внешнеэкономической деятельности (Внешэкономбанк)» на возмещение части затрат, связанных с поддержкой производства высокотехнологичной продукции».

$\rightarrow$ Постановление Правительства Российской Федерации от 7 марта 2019 года № 239 «0б установлении запрета на допуск отдельных видов товаров станкоинструментальной промышленности, происходящих из иностранных государств, для целей осуществления закупок для нужд обороны страны и безопасности государства».

$\rightarrow$ Постановление Правительства Российской Федерации от 29 марта 2019 года № 355-23 «0 внесении изменений в государственную программу Российской Федерации «Развитие промышленности и повышение ее конкурентоспособности».

$\rightarrow$ Постановление Правительства Российской Федерации от 12 декабря 2019 года № 1649 «0б утверждении Правил предоставления субсидий из федерального бюджета российским организациям на компенсацию части затрат на проведение научно-исследовательских и опытно-конструкторских работ по современным технологиям в рамках реализации такими организациями инновационных проектов и о признании утратившими силу некоторых актов Правительства Российской Федерации». 
Таблица 2. Структура рынка ведущих производителей М00, млрд руб. (Стаб. - стабильно)

\begin{tabular}{|c|c|c|c|c|c|c|c|c|c|c|c|c|}
\hline \multirow[t]{2}{*}{ Страна } & \multicolumn{4}{|c|}{2018 год } & \multicolumn{4}{|c|}{2019 год } & \multicolumn{4}{|c|}{2020 год } \\
\hline & $\begin{array}{l}\text { произ- } \\
\text { водство }\end{array}$ & $\begin{array}{l}\text { экс- } \\
\text { порт }\end{array}$ & импорт & рынок & $\begin{array}{c}\text { произ- } \\
\text { водство }\end{array}$ & $\begin{array}{l}\text { экс- } \\
\text { порт }\end{array}$ & импорт & рынок & $\begin{array}{c}\text { произ- } \\
\text { водство }\end{array}$ & экспорт & импорт & рынок \\
\hline Китай & 19,87 & 3,39 & 8,19 & 24,67 & 20,77 & 3,82 & 8,13 & 25,08 & Рост & Рост & Рост & Рост \\
\hline Германия & 12,57 & 8,98 & 3,02 & 6,61 & 12,35 & 8,42 & 2,89 & 6,82 & Падение & Падение & Падение & Падение \\
\hline Италия & 6,13 & 3,42 & 1,59 & 4,30 & 6,35 & 3,65 & 1,60 & 4,30 & Стаб. & Стаб. & Стаб. & Стаб. \\
\hline Япония & 11,35 & 7,57 & 0,85 & 4,63 & 10,58 & 6,81 & 0,87 & 4,64 & Стаб. & $\begin{array}{l}\text { Стаб./ } \\
\text { рост }\end{array}$ & $\begin{array}{l}\text { Стаб./ } \\
\text { рост }\end{array}$ & $\begin{array}{l}\text { Стаб./ } \\
\text { рост }\end{array}$ \\
\hline Россия & 0,52 & 0,05 & 0,87 & 1,33 & 0,56 & 0,05 & 0,92 & 1,42 & Рост & Рост & Рост & Рост \\
\hline США & 5,30 & 1,55 & 4,98 & 8,73 & 5,05 & 1,38 & 4,79 & 8,47 & Стаб. & Стаб. & Рост & Стаб. \\
\hline Чехия & 0,67 & 0,69 & 0,56 & 0,55 & 0,57 & 0,60 & 0,51 & 0,47 & Падение & Падение & Падение & Падение \\
\hline Швейцария & 3,36 & 2,85 & 0,59 & 1,09 & 2,75 & 2,35 & 0,65 & 1,05 & Падение & Падение & Стаб. & Падение \\
\hline Тайвань & 3,98 & 3,10 & 0,82 & 1,70 & 3,33 & 2,57 & 0,63 & 1,39 & Рост & Рост & Рост & Рост \\
\hline $\begin{array}{l}\text { Южная } \\
\text { Корея }\end{array}$ & 4,48 & 2,21 & 1,07 & 3,33 & 4,53 & 2,26 & 1,07 & 3,30 & Падение & Падение & Падение & Падение \\
\hline
\end{tabular}

США, Китай и Россия - это страны, в которых производство продукции сопоставимы с рынком потребления, а значит у этих стран рынок есть и он может развиваться (табл. 2).

У стран, в которых производство продукции существенно превышает рынок потребления, такая ситуация возможна благодаря государственной финансовой поддержке, направленной на развитие высокотехнологичного сектора экономики.

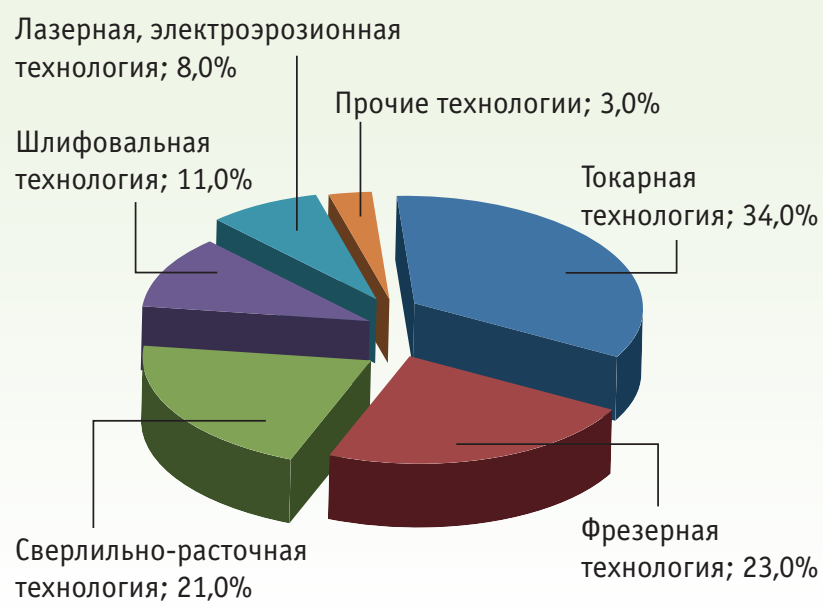

Puc. 7. Структура предприятий станкостроительного комплекса по технологическим направлениям в 2019 году

Структура предприятий (рис. 7) существенно не изменилась. Преобладают традиционно приоритетные технологические направления: токарное, фрезерное, сверлильно-расточное, шлифовальное.
Постепенно восстанавливается зубообработка и зубошлифование. Получают развитие лазерная и электроэрозионная технологии.

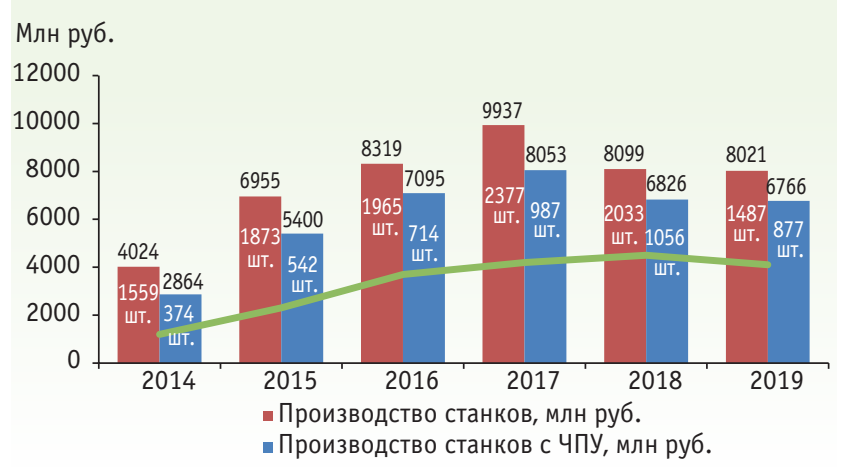

Puc. 8. Производство металлорежущих станков предприятиями Ассоциации «Станкоинструмент»

2019 год был самым худшим по выпуску станков с ЧПУ и обрабатывающих центров (рис. 8), хотя за последние 5 лет (с 2014 г.) наблюдалась позитивная динамика роста производства этих типов оборудования. Главными причинами такого положения стали недостаток оборотных средств, недостаточная поддержка по НИОКР, Постановления Правительства РФ от 7 марта 2019 года № 239 и от 17 июля 2015 года № 719, исчерпан потенциал, использованный в рамках программы развития станкоинструментальной отрасли. В сравнении с 2018 годом выпуск станков с ЧПУ сократился на $17 \%$ (в натуральном выражении), хотя в денежном выражении объем производства этих станков сохранился, практически, на прежнем уровне 
за счет ценового фактора (снижение всего лишь на $0,9 \%)$. Исправление ситуации во многом будет связано с реализацией концепции «Индустрия 4.0» и цифровизацией промышленности.

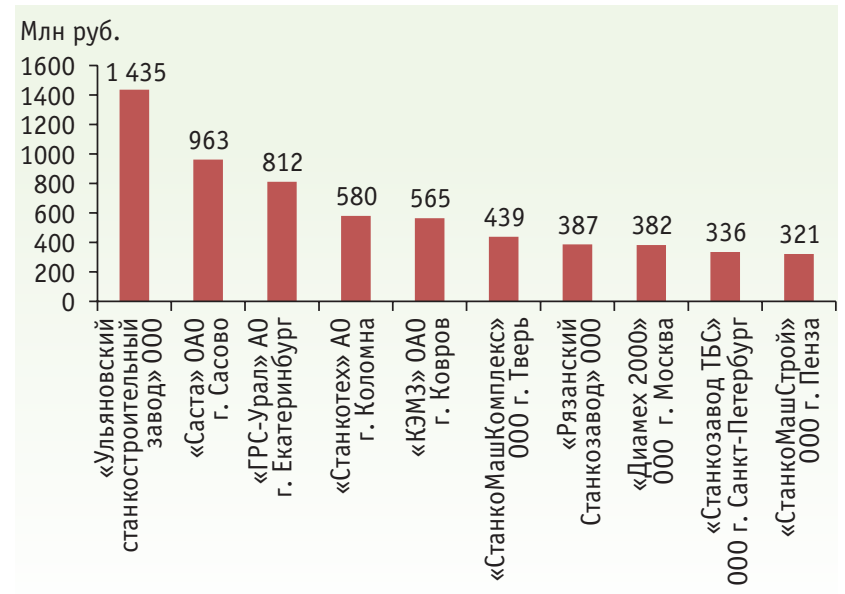

Puc. 9. Топ-10 предприятий станкостроительного комплекса по производству товаров и услуг в 2019 году

В числе 10 представленных предприятий (рис. 9), лидирующих по объемам производства, ряд предприятий, не имевших площадок, людей и оборудования, были вновь созданы за последние 5 лет. Это предприятия: ООО «Ульяновский станкостроительный завод», АО «ГРС Урал» (Екатеринбург), ПАО «Ковровский электромеханический завод», ОАО «СтанкоМашКомплекс» (Тверь), ООО «СтанкоМашСтрой» (Пенза).

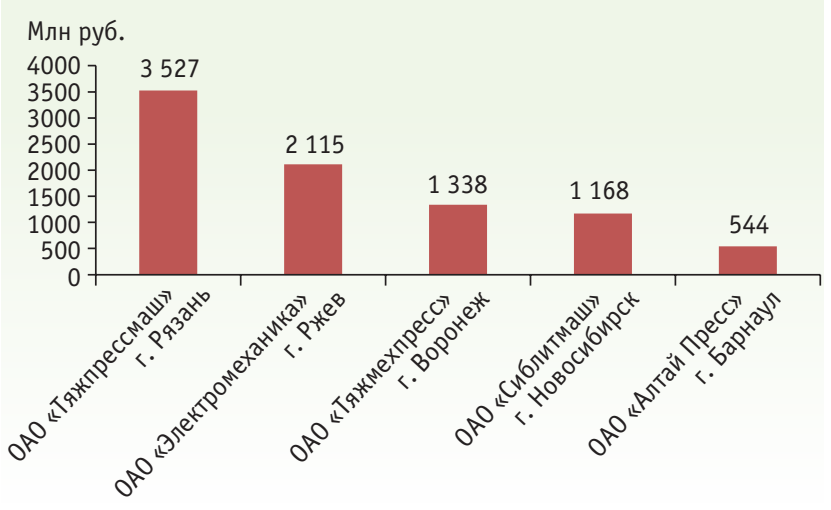

Puc. 10. Топ-5 предприятий производителей КП0 по производству товаров и услуг в 2019 году

Самый большой объем производства у «Тяжпрессмаш» (г. Рязань) (рис. 10). Поскольку загрузить имеющиеся мощности профильной продукцией не представляется возможным, все предприятия кузнечно-прессового комплекса, помимо основной деятельности, нашли ниши, позволяющие использовать свои технологические возможности для изготовления другой востребованной продукции.

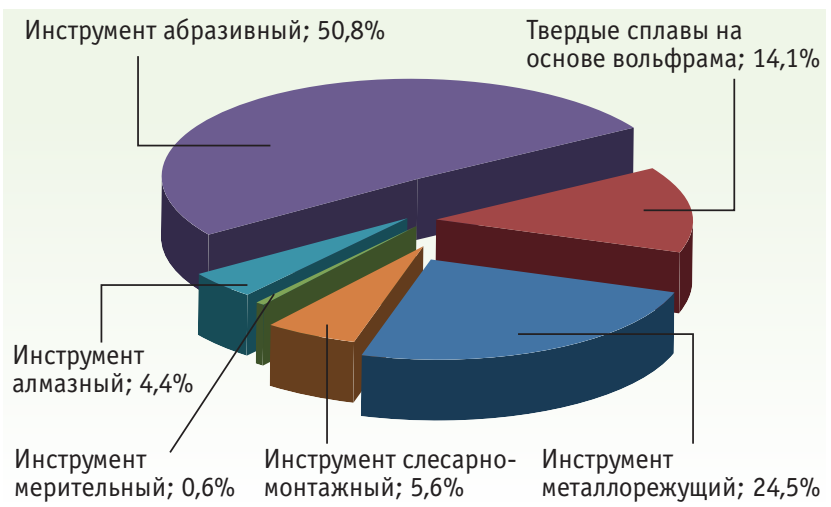

Puc. 11. Структура выпуска продукции предприятиями инструментального комплекса в 2019 году

Для анализа структуры выпуска продукции предприятиями инструментального комплекса (рис. 11) приняты показатели 39 предприятий, по которым: $\rightarrow$ выпуск товаров и услуг составил 26,6 млн руб., или 104,3\% к уровню 2018 года;

$\rightarrow$ инвестиции в производство составили 605,0 млн руб.

Заметно выделяется большой удельный вес абразивного инструмента, что объясняется номенклатурной спецификой инструментального производства.

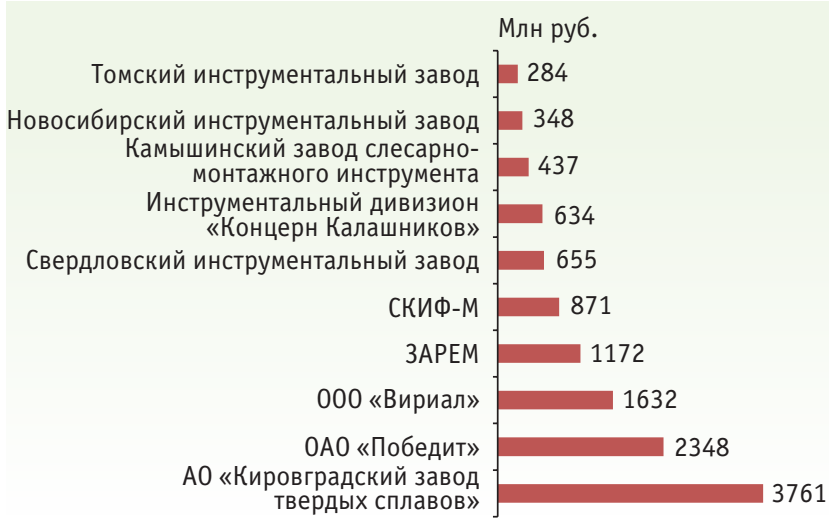

Puc. 12. Топ-10 предприятий инструментального комплекса по производству товаров и услуг в 2019 году

Показанные на слайде (рис. 12) первые три предприятия (АО «Кировградский завод твердых сплавов», ОАО «Победит», ООО «Вириал»), помимо выпуска специализированного твердосплавного инструмента, выпускают большое количество изделий с использованием твердых сплавов.

Характерными особенностями для предприятий инструментального комплекса являются наличие обширной номенклатуры выпуска изделий, наличие интеллектуальных, кадровых и технологических возможностей. Однако росту объемов выпуска продукции 
препятствует доминирование поставок иностранного инструмента - от 50 до 70\% (по разным направлениям).

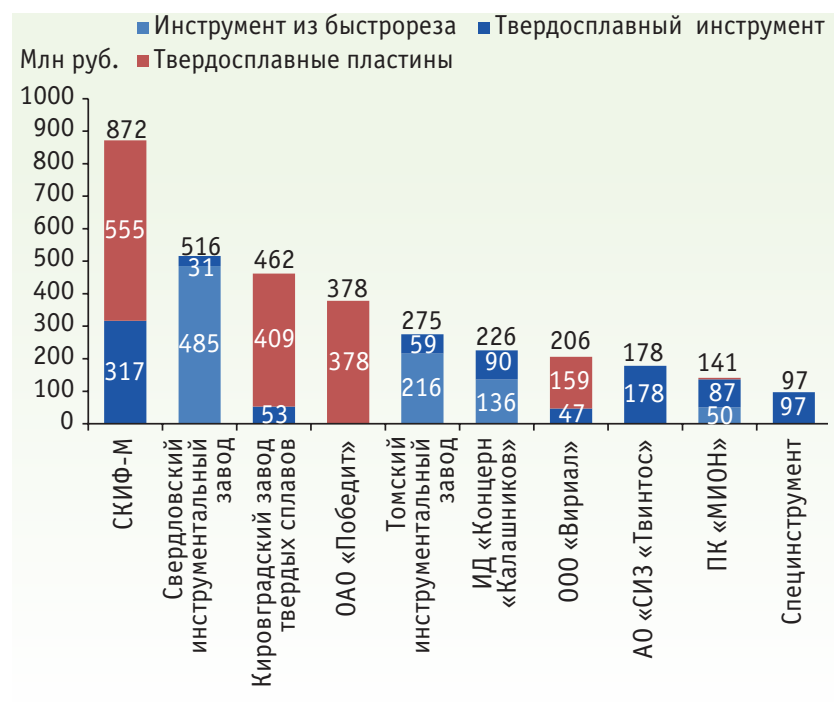

Puc. 13. Топ-10 предприятий по выпуску инструмента в 2019 году

Учитывая, что в работе станков с ЧПУ и обрабатывающих центров используется на 70-80\% твердосплавный инструмент, большинство предприятий имеет свои производства по изготовлению твердосплавных пластин и инструмента из быстрорежущей стали (рис. 13).

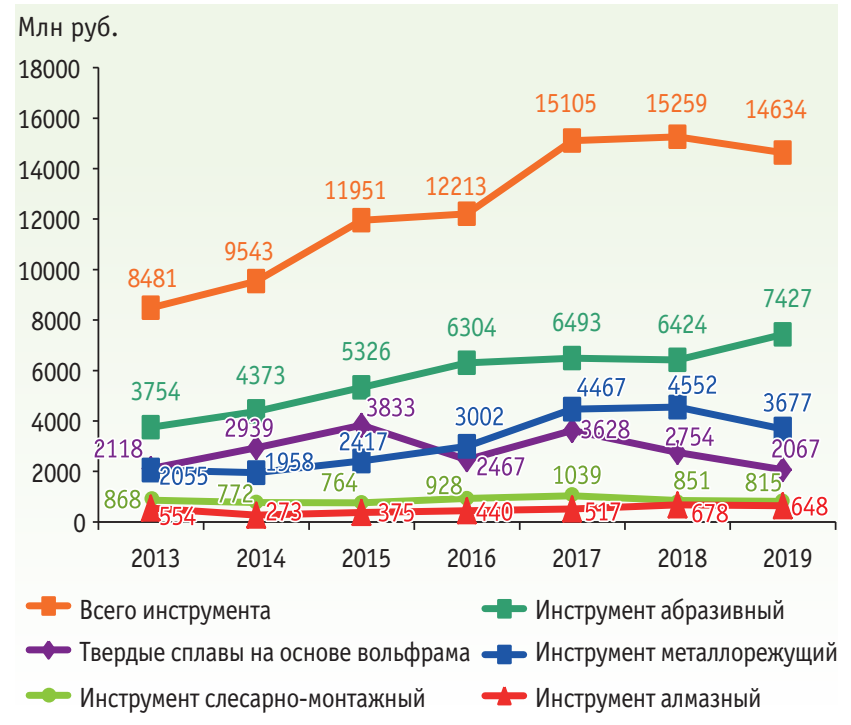

Puc. 14. Производство инструментальной продукции предприятиями Ассоциации «Станкоинструмент»

Сегодня российские инструментальные заводы (рис. 14) имеют возможность выходить на российский рынок потребления оборудования. Все станкостроительные и прессостроительные заводы, которые поставляют свою продукцию, обязательно оснащают изделия набором определенного инструмента, практически без

\section{НАИБОЛЕЕ СЛОЖНЫЕ ПРОБЛЕМЫ ОТРАСЛИ, ТРЕБУЮЩИЕ СИСТЕМНОГО РЕШЕНИЯ}

Проблемы, связанные с производством:

1. в 2019 году 12 предприятий использовали возможности программы «Станкостроение» Фонда развития промышленности (ФРП) как важный источник получения финансовой поддержки на техническое перевооружение производства. Займы до 500 млн руб. на срок до 7 лет под 1\% (первые 3 года) и 5\% (на оставшийся срок);

2. пункт 6 поручения Президента России о мерах дополнительной поддержки предприятий станкостроения, в том числе направленных на пополнение оборотных средств;

3. доработка постановлений в целях решения проблемы оборотных средств;

4. внесение изменений в Постановление от 17 июля 2015 года № 719, в том числе по уровню локализации: 000 «ВЗСП» (г. Вологда) - подшипники, фирма SKF - шпиндели, ОАО «Ковровский электромеханический завод».

\section{Проблемы научно-технической деятельности и инновации:}

1. Постановление от 12 декабря 2019 года № 1649 (субсидирование из федерального бюджета НИОКР);

2. взаимодействие с Инженерным центром FANUC (Сколково) в целях обучения и разработки инженерных решений в вопросах автоматизации;

3. взаимодействие с Институтом машиноведения им. А.А.Благонравова Российской академии наук (ИМАТТТ РАН) - фундаментальные исследования, научно-техническая политика);

4. взаимодействие с институтом НТИМИ (цифровизация, аддитивные технологии).

\section{Проблемы, связанные со сбытом на внутреннем рынке:}

1. принимаются решения по внесению кардинальных изменений в Федеральный закон от 5 апреля 2013 года № 44-Ф3; проводится работа в Межведомственной рабочей группе в рамках Постановлений Правительства РФ от 14 января 2017 года № 9 и от 7 марта 2019 года № 239;

2. вносятся изменения и корректировки в постановление от 17 июля 2015 года № 719;

3. сотрудничество с В/0 «Станкоимпорт» в сфере государственных интересов;

4. сотрудничество с Центром управления проектами в промышленности Минпромторга России. 


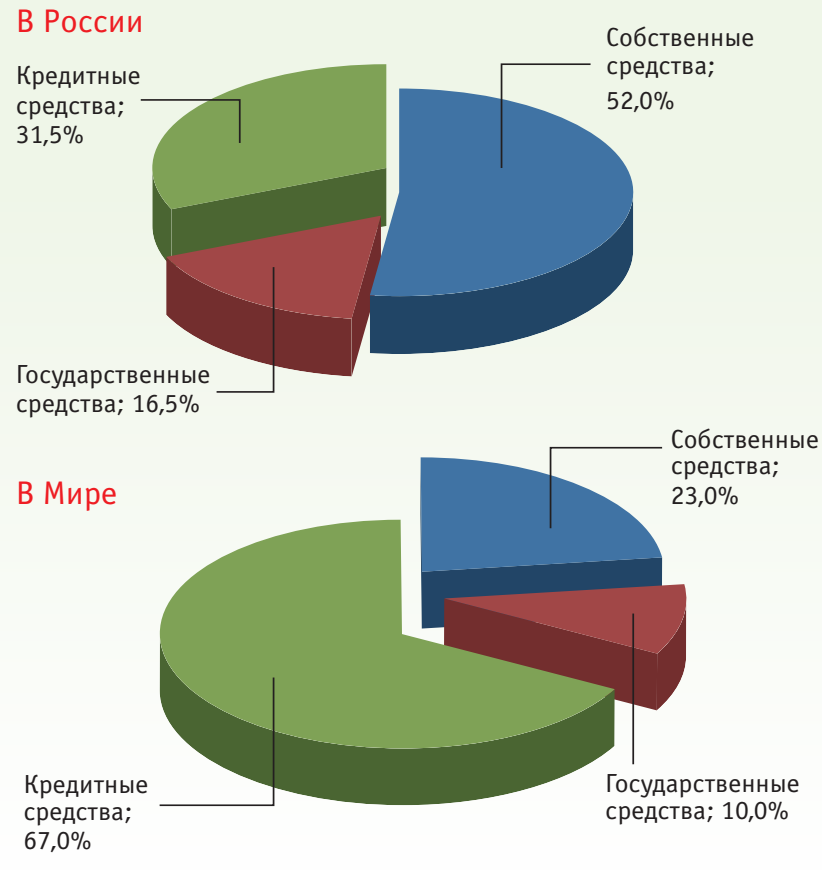

PUC. 15. Источники финансирования проектов

участия отечественных производителей инструмента. Лишь 15-20\% изготавливаемого металлообрабатывающего оборудования комплектуются инструментом в основном, потребитель оборудования предпочитает оснащать его закупаемым инструментом.
Производство инструмента за 2019 год к уровню 2018 года составило:

$\rightarrow$ абразивный инструмент - 7,021 млрд руб., или $102,2 \%$;

$\rightarrow$ металлорежущий инструмент - 3,59 млрд руб., или $100,1 \%$;

$\rightarrow$ твердосплавный инструмент - 2,53 млрд руб., или $105,6 \%$;

$\rightarrow$ слесарно-монтажный инструмент - 0,815 млрд руб., или 95,6\%;

$\rightarrow$ алмазный инструмент - 0,263 млрд руб., или 90,2\%;

$\rightarrow$ сплавы на основе вольфрама - 2,07 млрд руб., или $75,0 \%$;

$\rightarrow$ контрольно-измерительные приборы и инструмент - 0,087 млрд руб., или 100,7\%.

Только в России реализация инвестиционных проектов осуществляется в основном за счет собственных средств, тогда как в мире такая реализация осуществляется за счет заемных средств (рис. 15).

\section{САМОдУРОВ Георгий Васильевич -}

кандидат технических наук, президент Ассоциации «Станкоинструмент», член-корреспондент Российской инженерной академии

\section{ЛАХТЮХОВ Дмитрий Валерьевич -}

директор по связям с отраслевыми ассоциациями и стандартизации Ассоциации «Станкоинструмент»

\section{КНИГИ ИЗДАТЕЛЬСТВА «ТЕХНОСФЕРА»}

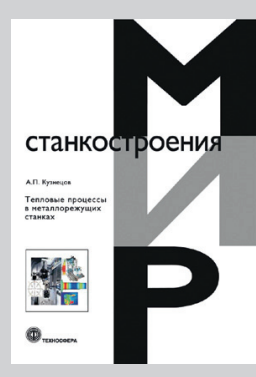

Цена 1090 руб.

\section{ТЕПЛОВЫЕ ПРОЦЕССЫ}

В МЕТАЛЛОРЕЖУЩИХ СТАНКАХ

\section{Кузнецов А.П.}

В книге рассматриваются методы оценки теплового режима металлорежущих станков и их наиболее теплонапряженных деталей и узлов. Приведен механизм формирования и теплофизического анализа теплового режима деталей и узлов металлорежущих станков, дана их теплофизическая классификация и описываются типовые тепловые модели. Приводятся аналитические зависимости для оценки стационарного и нестационарного теплового режимов деталей и узлов станков.

Приведена классификация методов воздействия на тепловой режим станков, описаны способы снижения, коррекции, компенсации и управления тепловым режимом металлорежущих станков.

Предлагаемая монография может быть полезна студентам, аспирантам, а также инженерам и специалистам, занимающимся вопросами повышения точности при проектировании, производстве и эксплуатации металлорежущих станков. 

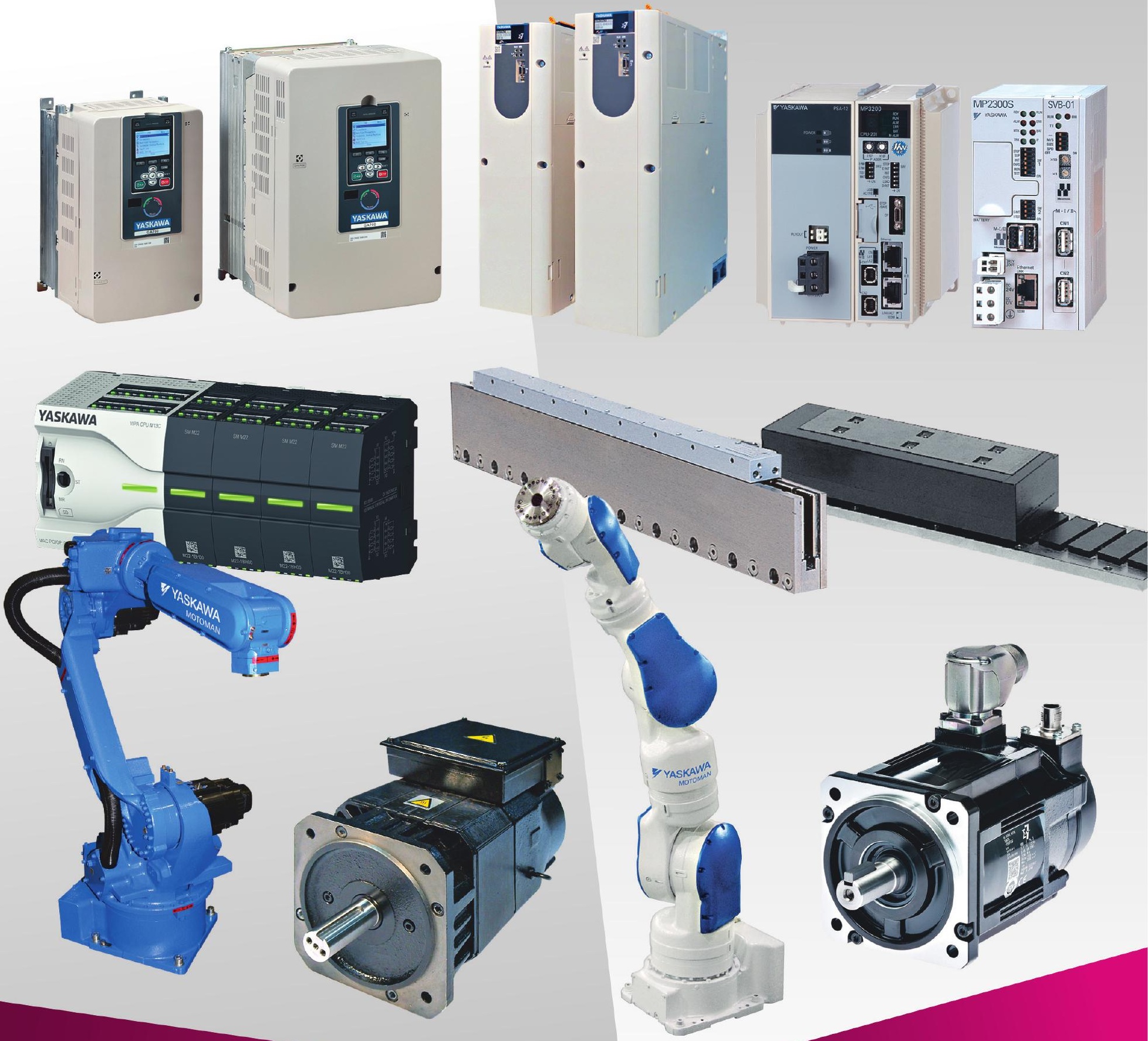
- Преобразователи частоты от 0,4 до 12000 кВт
- Шпиндельные двигатели
- Комплектные сервоприводы от 0,003 до 75 кВт
- Линейные сервосистемы
- Контроллеры управления движения
- Программируемые логические контроллеры
- Роботы

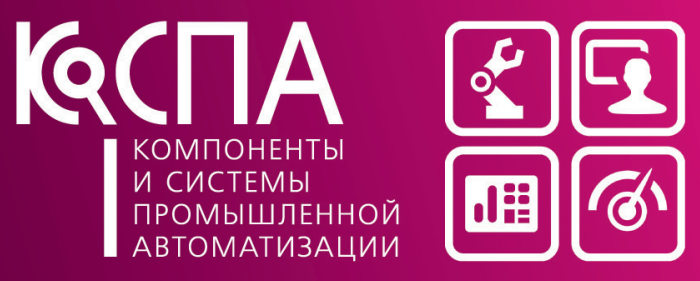

+7 (495) 660-28-22; www.cospa.ru

ООО «КОСПА»ОФИЦИАЛЬНЫЙ ПАРТНЕР И СЕРВИСНЫЙ ЦЕНТР YАSКАWA 